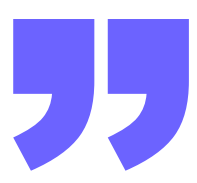

\title{
THE PROBLEMS OF LEARNING ENGLISH VOCABULARY IN HARAPAN SENIOR HIGH SCHOOL
}

\author{
Ni Putu Ari Krisnayanti, I.B. Gde Nova Winarta \\ Faculty of Foreign Languages, Mahasaraswati Denpasar University \\ arikrisnayanti9@gmail.com, idabagusnova@unmas.ac.id
}

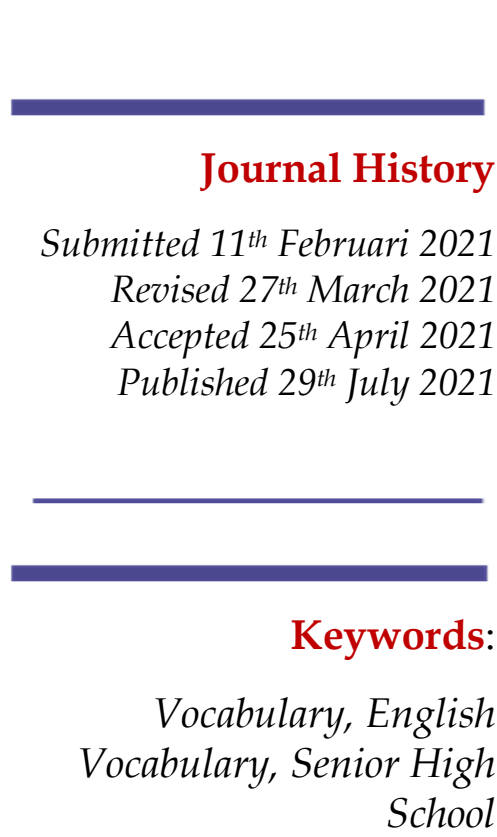

\begin{abstract}
The aim of this study is to find out the problems in learning English Vocabulary especially in the eleventh-grade students of Harapan Senior High School Denpasar. This study used quantitative method and also supported by descriptive qualitative method to help the quantitative explanation. In this study, the writer had 70 students of 11 social 2 and 11 social 3 at eleventhgrade students in Harapan Senior High School Denpasar. The writer gave a test to the participants. Since this study has purpose to know the students' problem in learning vocabulary, the writer also interviewed 3 students who got lower score than other students to get rich description of the problems. The eleventh-grade students still have many difficulties in vocabulary learning. The categorization of the student problem is based on vocabulary learning aspects, such as pronunciation, spelling, word meaning and word use. The average score that the students got in pronunciation is $81,43 \%$, in spelling is $59,71 \%$, in word meaning is $71,02 \%$, and in word use the students got $73,33 \%$. So, the students still have problems in vocabulary. Furthermore, the problem can be caused by many factors, such as: hard to memorize many words, their motivation, or lack of experience in language learning.
\end{abstract}

\section{INTRODUCTION}

Language is a communication tool to convey ideas, messages or information is in people mind which can be conveyed spoken or written. World has many countries that have various cultures, languages, foods, and many things that other country didn't have. Therefore, people need 
language to transfer messages or making a deal with someone else. English language is one of the foreign languages that most of countries select as an international language. As an international language, English widely used by people in the world and we should learn English as a second language. English as a language communication is clearly needed by many people to deliver or interact with another people in the variety situation. Around the world, especially in Indonesia people have learnt English from childhood. Although they have learnt English since childhood, they still get problems when learning English. They believe English is worst subject that have lots of vocabulary, difficult pronunciation, spelling and hard to find suitable meaning.

Vocabulary is an essential component in language proficiency and determines how well learners listen, speak, read and write (Richards and Renandya, 2002). In Harmer's book (2001, as cited in Ningrum 2015), there are some aspects that should be discussed in vocabulary, such as: pronunciation, spelling, word meaning (synonym, antonym, connotation, and denotation), and extending word use (idioms, word combination or collocation). Those are the aspects that make students find many problems to learn English.

Moreover, there are many factors that make the students found problems in learning English vocabulary such as linguistics and nonlinguistics factor. Linguistics factor is related to language difficulties (grammar or the rules that language used). There are 2 kinds of nonlinguistics factor such as, internal factors (related to peoples' motivation, interest, and memories the words) and external factors (related to teaching method, environment, or situation). Based on the explanation, the writer are interested to conduct research about knowing the common problems in vocabulary learning.

The aim of this study is to know the problems that faced by the students especially in Harapan Senior High School. The school was chosen because the students are not interested in learning language. It can be seen when the students are doing online learning in Google Meet or Zoom Meeting because of COVID-19, they are not excited when learning English language than learning other subjects. It is supported when the writer asked 4-5 students in that school why they didn't interest in learning English. It is interested to analyze because they are not interested with English because of its difficult structure, pronunciation or grammar. Then, this study focused on the discussion of students' problem in learning English vocabulary especially in pronunciation, spelling, word meaning and using word appropriately. 


\section{METHODS}

The data was taken in Harapan Senior High School. The school is located on Jalan Raya Sesetan number 62, Denpasar. The participants were from eleventh-grade of senior high school students. There are 10 classes that consist of 350 students and after asked permission to the teacher gave 2 classes of eleventh-grade with 70 students for the participants.

This study used quantitative method supported by qualitative method. In quantitative method, the writer conducted a test and then distributed to the participants in Google Form. The writer got the questions from Nunik Rahmawati by using this instrument and she already been practiced for the students in that school. The test was provided with 4 multiple choices of 20 questions. There were 4 sections in this test based on Harmer's opinion in his book and the score presented by using table. Also, the writer conducted the interview in qualitative method. The interview conducted after the score of the test is listed, then conducted interview for the students who have lower score than other students and the writer got 3 students for the participants in the interview.

\section{RESULTS AND DISCUSSION}

\section{Students' Score in Pronunciation}

\begin{tabular}{|c|c|c|c|c|c|c|c|}
\hline \multirow[t]{2}{*}{ No } & \multirow{2}{*}{\multicolumn{2}{|c|}{ Question Item }} & & \multicolumn{4}{|c|}{ Students' Score } \\
\hline & & & & Correct & Score & Incorrect & Score \\
\hline 1 & $\begin{array}{l}\text { Question } \\
\text { "huge" }\end{array}$ & 1 about & pronounce & 50 & 71,43 & 20 & 28,57 \\
\hline 2 & $\begin{array}{l}\text { Question } \\
\text { "leaves" }\end{array}$ & 2 about & pronounce & 63 & 90 & 7 & 10 \\
\hline 3 & $\begin{array}{l}\text { Question } \\
\text { "bumps" }\end{array}$ & 3 about & pronounce & 58 & 82,85 & 12 & 17,15 \\
\hline 4 & $\begin{array}{l}\text { Question } \\
\text { "roast" } \\
\end{array}$ & 4 about & pronounce & 59 & 84.28 & 11 & 15,72 \\
\hline 5 & $\begin{array}{l}\text { Question } \\
\text { "beak" }\end{array}$ & 5 about & pronounce & 55 & 78,57 & 15 & 21,43 \\
\hline \multicolumn{4}{|c|}{ Average Score } & $81,43 \%$ & & $18,57 \%$ & \\
\hline
\end{tabular}

The table showed that $81,43 \%$ of students had no problems in answered the questions and $18,57 \%$ of them still had the problems in answered the question about pronouncing the word. It can be seen from the table, the question number 1 has lowest percentage in pronunciation section. The word "huge" they were 50 students answer correctly and 20 of them are failed. Also the writer conducted interview to the students who have lowest score and said: 
"Hulk kan soalnya besar (in the film) yaudah tak pilih hulk aja. Saya juga taunya large itu 'besar' terus kalo 'very large' gatau, yaudah jawab hulk aja" (Student 1 )

"Hulk is a big man (in the film), so I choose hulk for the answer. I only know large means 'besar' and I do not know the meaning of 'very large', so I choose hulk for the answer" (Student 1)

All the participants have problems in pronouncing the words because the pronunciation between word and spelling is different and become their difficulty in learning English. Furthermore, Hulk was not the answer. Hulk is one of the character superhero in the film of Marvel Universe, he has huge body and has green color all over his body. They chose that answer because he has similar body characteristics with Hulk in the film. And most of students were not familiar with the word pronunciation, so they chose an approaching answer.

\section{Students' Score in Spelling}

\begin{tabular}{|c|c|c|c|c|c|}
\hline \multirow[t]{2}{*}{ No } & \multirow[t]{2}{*}{ Question Item } & \multicolumn{4}{|c|}{ Students' Score } \\
\hline & & Correct & Score & Incorrect & Score \\
\hline 1 & Question 6 about spelling /i/ & 41 & 58,57 & 29 & 41,43 \\
\hline 2 & Question 7 about spelling /i:/ & 53 & 75,71 & 17 & 24,29 \\
\hline 3 & $\begin{array}{l}\text { Question } 8 \text { about spelling } \\
\text { /k/ }\end{array}$ & 45 & 64,29 & 25 & 35,71 \\
\hline 4 & $\begin{array}{l}\text { Question } 9 \text { about spelling } \\
\text { /ai/ }\end{array}$ & 44 & 62,86 & 26 & 37,14 \\
\hline 5 & $\begin{array}{l}\text { Question } 10 \text { about spelling } \\
\text { /z/ }\end{array}$ & 26 & 37,14 & 44 & 62,86 \\
\hline \multicolumn{2}{|c|}{ Average Score } & \multicolumn{2}{|l|}{$59,71 \%$} & \multicolumn{2}{|l|}{$40,29 \%$} \\
\hline
\end{tabular}

This table showed that 59,71\% students could answer the questions correctly and 40,29\% still had problems in answer the questions about spelling. This case is quite similar with pronunciation section. The basic problem in learning spelling in English is because the ways in reading word are totally different. One syllable had more than one way in utterance and it is vice versa with Bahasa Indonesia. Based on the interview that had conducted the participants were not taught by the teacher how to spell the word well and they just learnt how to read the word with a repetition and it made them found difficult in spelling the words.

"Gak pernah tapi pernah denger aja. Saya gapernah belajar itu soalnya" (Student 1)

"Never but I have heard of it. I never studied about spelling before" (Student 1)

According to Ur (1996:60), there are several important points that must be considered when teaching vocabulary, namely the form of 
pronunciation and spelling. The learners have to know what word sound is like (pronunciation) and what it looks like (spelling). In this case the students never study about what sounds look like, therefore they found difficulties to decide what the correct answer in the test. The students were taught by method repeating the words and the students will follow the teacher, it makes students bored in learning process and they did not know the meaning of the word in sentence.

Students' Score in Word Meaning

\begin{tabular}{|c|c|c|c|c|c|}
\hline \multirow[t]{2}{*}{ No } & \multirow[t]{2}{*}{ Question Item } & \multicolumn{4}{|c|}{ Students' Score } \\
\hline & & Correct & Score & Incorrect & Score \\
\hline 1 & $\begin{array}{l}\text { Question } 11 \text { about meaning of } \\
\text { "present" }\end{array}$ & 56 & 80 & 14 & 20 \\
\hline 2 & $\begin{array}{l}\text { Question } 12 \text { about meaning of } \\
\text { "pepper" }\end{array}$ & 56 & 80 & 14 & 20 \\
\hline 3 & Question 13 about meaning of "jokes" & 55 & 78,57 & 15 & 21,43 \\
\hline 4 & Question 14 about meaning of "lives" & 18 & 25,71 & 52 & 74,29 \\
\hline 5 & Question 15 about meaning of "hard" & 60 & 85,71 & 10 & 14,29 \\
\hline 6 & Question 16 about meaning of "like" & 59 & 84,29 & 11 & 15,71 \\
\hline 7 & Question 17 about meaning of "clean" & 44 & 62,86 & 26 & 37,14 \\
\hline \multicolumn{2}{|c|}{ Average Score } & $71,02 \%$ & & $28,98 \%$ & \\
\hline
\end{tabular}

In the table above showed $71,02 \%$ students can answer correctly and the other hand $28,98 \%$ of students failed in answered the questions about meaning. In question 15 about meaning "hard" many students got wrong answer. It happened because the students realized "hard" has one meaning "keras". And also most of the teacher when teach English to students with the way translating the meaning into Bahasa Indonesia, it makes they do not know the word meaning in the sentence and do not know the synonym of the word.

"Dari dulu taunya 'clean' itu 'membersihkan' gitu kayak 'My mother cleans bathroom' gitu, terus di soalnya ini kan 'clean socks' gitu jadinya saya kira dia itu membersihkan kaosnya" (Student 1)

“I just know 'clean' means 'membersihkan' for example 'My mother cleans bathroom' and for the question about 'clean socks', I thought if she/he was cleaning her/his socks"' (Student 1).

From the students that had been interviewed, all of them have decided meaning as their problem in translation. Less knowledge about vocabulary make them hard to know the appropriate meaning and then they decided the answer with what is often seen and heard. Also they realized English as easy as Bahasa Indonesia which have one meaning in a word but in fact is not. 
Students' Score in Word Use

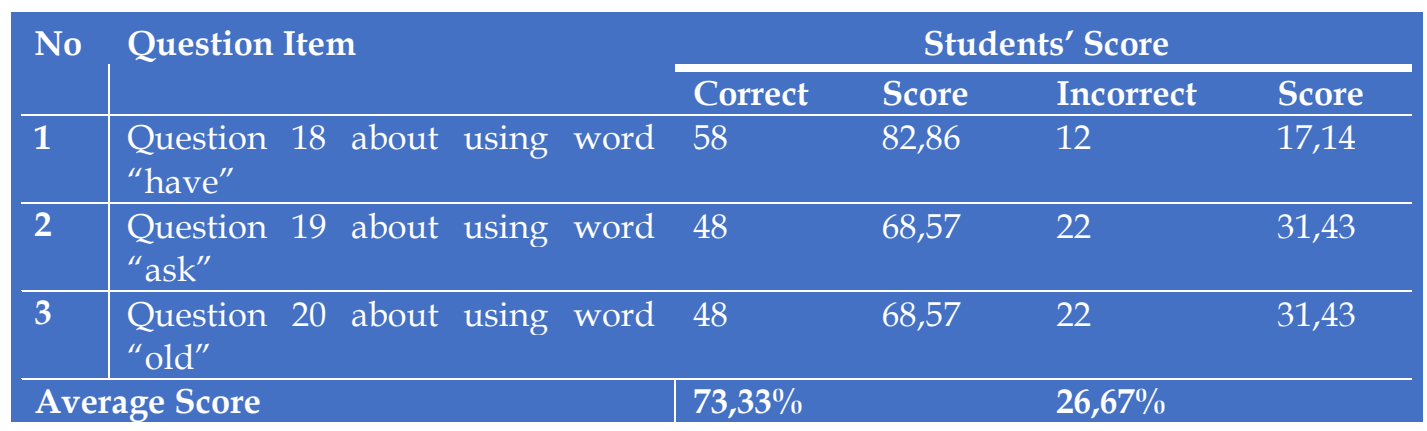

From the table showed that, there were $73,33 \%$ of students answered correctly and automatically $26,67 \%$ of students had problems in answered the questions about using word. Many kinds of meaning of the word made students confused in deciding the meaning correctly based on the context. Less knowledge about meaning of the students made the students stuck in comprehending the word.

"Saya dari dulu tau kalau 'old' itu artinya 'tua' tapi kalo saya liat di soalnya saya berpikir semua artinya kok 'tua' ya. Yaudah saya pilih yang Homo Sapiens itu, dia kan hidupnya udah lama jadi tua. Gitu aja sih kak" (Student 2)

"I've always known that 'old' means 'tua' but when I looked at the question, I think everything it means 'tua'. So, I choose the Homo Sapiens because they have been living for a long time and make them old. Just like that, sis" (Student 2)

Similar problem with meaning, using the word also make the students confused in placing where the word has to use. Their limited knowledge about the use makes them hard in deciding the meaning use in the context and they only know common meaning of word.

\section{CONCLUSION}

From the research that has been done about the problems in learning English vocabulary faced by the eleventh-grade students of Harapan Senior High School, the writer concludes that: the average score in the test are $81,43 \%$ in pronunciation section, $59,71 \%$ in spelling section, $71,02 \%$ in word meaning and got $73,33 \%$ in word use. So, the students still have problems in learning English vocabulary. Furthermore, the problems can be caused by many factors, such as the students' motivation, talent, interest and the students' experience in vocabulary mastery. 


\section{REFERENCES}

Berne, J.I., and Blachowicz, C. L. Z, (2008). what reading teachers say about vocabulary instruction: Voices from the classroom. The Reading Teacher 62 (4).314-323

Hornby. (1995), Oxford Advanced Learners' Dictionary of Current English, Fifth Edition. New York: Oxford University Press.

Jackson, H. and Amvela, E. Z. (2000). Words, Meaning And Vocabulary. London: Cassell.

James, B. (1994). Comprehensive Guide to Master of English. Singapore: Fairfield Book Publishers PTE LTD.

Ningrum, Wahyu. 2015. Students' Problem in Learning Vocabulary at Eight Grade in One of Junior High School in Jambi. Jambi: Universitas Jambi

Piaget (2008). Retrieved 2020, from http:/ / eprints.umg.ac.id/2919/3/BAB\%20II.pdf

Rachmawati, Nunik. 2012. Difficulties in English Vocabulary Learning Experienced by The Eighth-Grade Students Of SMP Negeri I Borobudur in The Academic Year of 2011/2012. Yogyakarta: Universitas Negeri Yogyakarta

Sarwono (2007). Retrieved 2020, from http:/ / eprints.umg.ac.id/2919/3/BAB\%20II.pdf

Richards, J.C., and Schmidt, R. 2002. Longman Dictionary of Language Teaching and Applied Linguistics. London: Pearson Education Limited

Ur, Penny. 1996. A Course in Language Teaching, Practice and Theory. Cambridge: Cambridge University Press. 